\title{
SÍDLIŠTĚ A POHŘEBIŠTĚ NITRANSKÉ KULTURY V HULÍNĚ 3-U POTƯČKU ${ }^{1}$
}

\author{
E V A S C H I M E R O VÁ
}

\begin{abstract}
Settlement and Cemetery of Nitra Culture from Hulín 3-U Potǔčku. This article is dedicated to a site of Nitra culture where settlement and cemetery were laid out next to each other. We will dicuss the layout of the site, the inventory, which was not numerous but significant. We have also ${ }^{14} \mathrm{C}$ dates, anthropological, paleobotanical and petrographical analysis that completes picture about this Early Bronze Age culture.
\end{abstract}

Keywords: Moravia, Early Bronze Age, Nitra culture, settlement, cemetery.

\section{ÚVOD}

Lokalita Hulín 3 se nachází na katastrálním území Hulína v trati U Potůčku. Byla zkoumána Archeologickým centrem Olomouc celkem dvakrát. V letech 2005-2006, byla během dvou sezón prozkoumána hlavní plocha výzkumu v rámci stavby dálnice. Poté $\mathrm{v}$ roce 2008 byl v sousedství hlouben výkop pro melioraci. V severní části zkoumané plochy bylo objeveno pohřebiště nitranské kultury čítající 101 hrobů. Na zbytku plochy bylo rozptýleno v malých skupinkách 35 sídlištních jam. Většina byla bez nálezů, nebo byly datované do novověku. Skupina pěti objektů obsahovala keramiku ze starší doby bronzové (Berkovec 2007).

Na souboru nálezů byly provedeny následující analýzy: antropologickou analýzu provedla Anna Pankowská, analýzu surovin kamenné industrie provedl Antonín Přichystal, analýzu rostlinných makrozbytků provedli Petr Kočár a Lucie Hendrychová a určení otisků ječmene z povrchu nádoby provedl Zdeněk Vaněček.

\section{SÍDLIŠTĚ}

S ohledem na velikost zkoumané plochy, bylo sídlištních objektů velice málo. Kromě pěti objektů, které se podařilo přiřadit ke starší době bronzové, zbytek obsahoval novověkou keramiku. Tyto objekty (č. 16-20) tvořily obloukovité seskupení v jihozápadní části plochy (obr. 1: 3). Pro dataci byl klíčový objekt 16, který obsahoval část hrnku s prožlabeným ouškem z jemné hlíny s příměsí drobných kamínků (obr. 2: 1). Tento typ hrnků se vyskytuje v nitranských hrobech, např́klad v hrobě 420 v Jelšovcích (Bátora 2000, tab. 36). Podobné hrnky se nacházejí i v protoúnětické kultuře, starší fázi únětické kultury, ale také $\mathrm{v}$ kultuře wieselburské (Bátora 2000, 312). Kromě toho zde bylo už jen pár zlomků nezdobené keramiky, zvírecí kosti a kameny. Objekt 17 obsahoval zlomek nezdobené keramiky. V objektu 18 byl zlomek okraje s hrdlem, který materiálově odpovídal části nádoby nalezené v objektu 16. V objektu 19 byla spodní část nádoby $\mathrm{s}$ kompletním dnem $\mathrm{z}$ velmi špatně vypálené keramiky (obr. 2: 6). Nádoba byla nezdobená, ale profilací odpovídala nitranské keramice, měla dno menšího průměru a doširoka se rozevírající stěny. Všechna keramika měla príměs drobných kamínkủ a jemnou a křehkou svrchní vrstvu. Z dalších nálezů máme už jen pět zlomků mazanice $\mathrm{z}$ objektu 18 , zvířecí kosti byly $\mathrm{v}$ malém množství ve všech objektech, kromě objektu 18 s 118 zlomky. Objekty 16 a 18 obsahovaly každý po dvou kamenech. Torzo nádoby z hrobu 19 mělo ve spodní části tři otisky obilných zrn (obr. 2: 7, 8). Povrch nádoby je značně erodovaný, proto je možné s vysokou pravděpodobností určit pouze jeden z nich. Po zhotovení odlitků byl identifikován pravděpodobně otisk obilky ječmene setého (Vaněček 2014, 1). Ječmen byl nalezen i jako příměs v zásypu osmi hrobů (Hendrychová/Kočár 2007, 13).

Jak víme, objekty byly seskupené do půlkruhu, izolované od ostatních. Otázkou je, jestli mohly být seskupené kolem nějaké konstrukce, po které se nedochovaly žádné další stopy. Podobné seskupení tvořily ještě objekty $8,9,10$ a 11 , ale ty byly bez nálezů (obr. 1: 1). Absence konstrukčních prvků a staveb je pro nitranská sídliště typická, stejně tak volné plochy mezi objekty. Uvažuje se i ojiném typu staveb, nejčastěji se hovoří o srubových stavbách (Peška/Tajer 2015, 78). Zajímavou analogii mohou představovat domy mrtvých, které se občas vyskytují nad nitranskými hroby. V Ludanicích - Mýtne

\footnotetext{
1 Tento článek vychází z diplomové práce autorky, která byla obhájena v roce 2014 na Univerzitě Komenského v Bratislavě. Materiál byl zapủjčen a zpracován se svolením Arrcheologického centra Olomouc.
} 


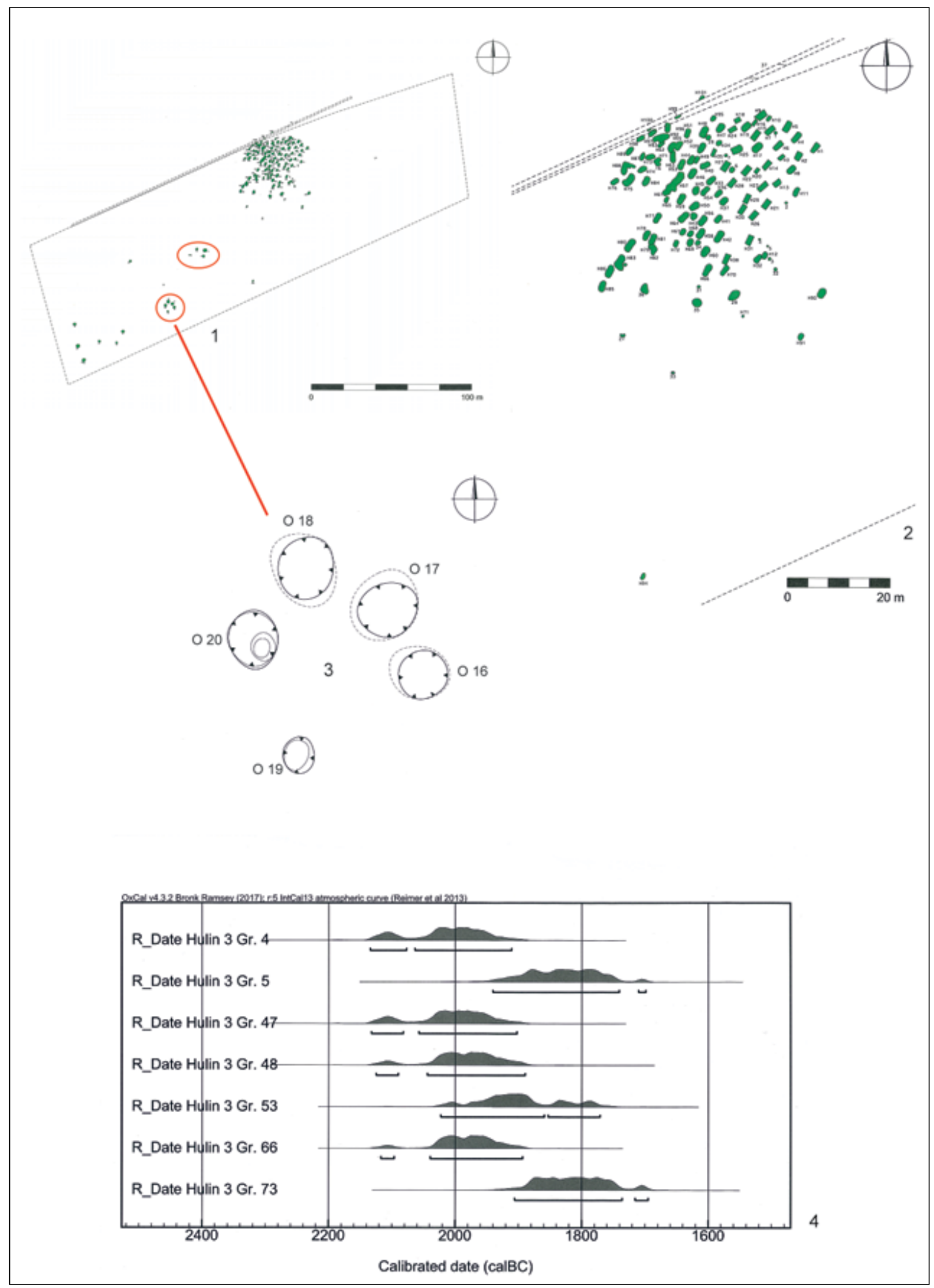

Obr. 1. Hulín 3-U Potůčku. 1 - celkový plán zkoumané plochy všech etap výzkumu; 2 - plán pohřebiště; 3 - rozmístění sídlištních objektů řazených k nitranské kultuře; 4 - radiokarbonová data získaná z hrobů (podle Peška/Tajer 2015, 7). 


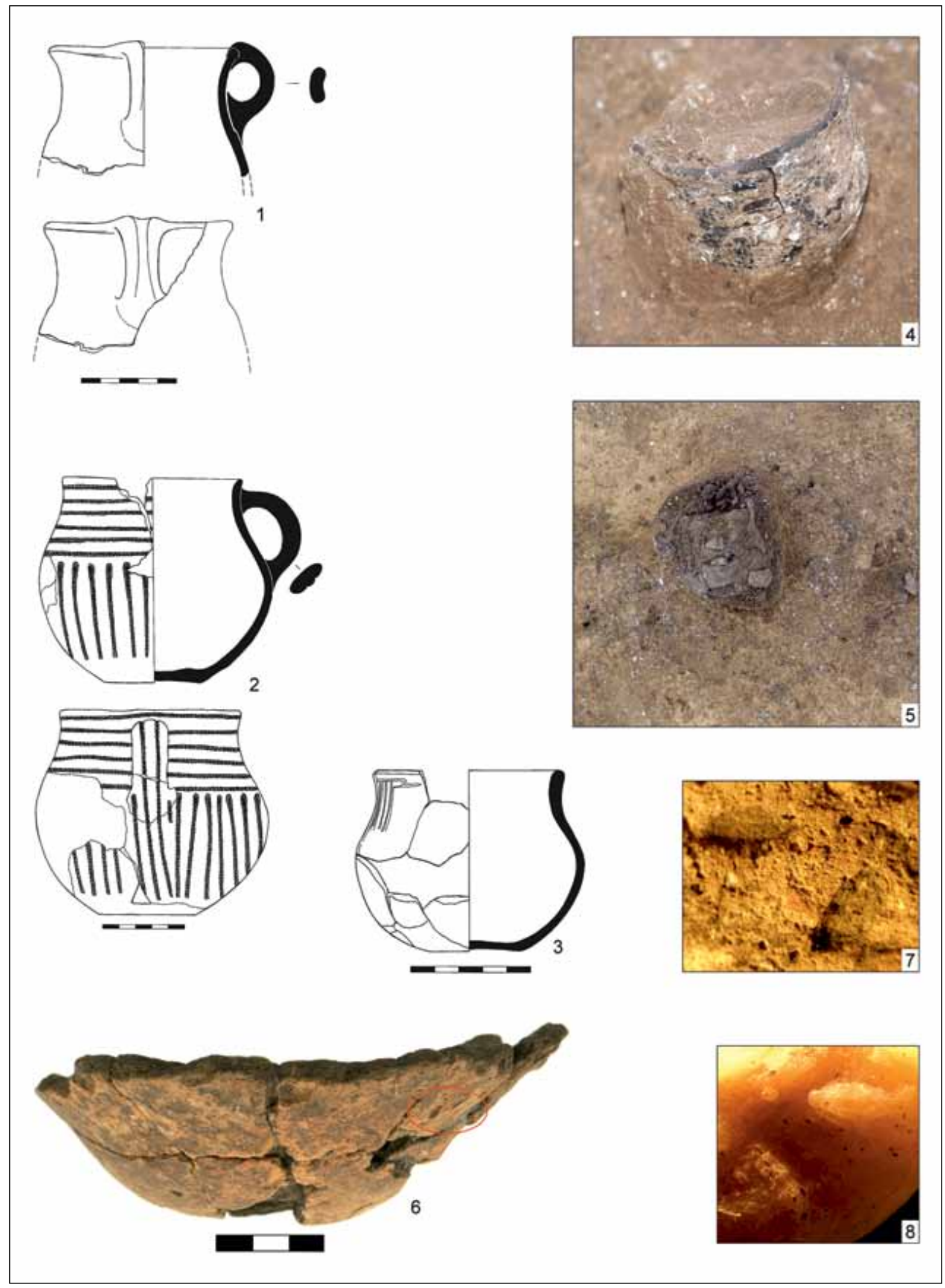

Obr. 2. Hulín 3-U Potůčku. 1 - část hrnku z objektu 16; 2 - džbánek z hrobu 65; 3 - hrnek z hrobu 74; 4 - hrnek z hrobu 57; 5 - nádoba z hrobu 79 (kresby M. Schindlerová); 6 - spodní část nádoby s otisky ječmene z objektu 19 (foto E. Schimerová); 7 - detail otisků ječmene z nádoby; 8 - voskový otisk zrn (foto Z. Vaněček). 
Nové Vsi se dochovaly kůlové struktury nesoucí patrně lehčí konstrukce, naproti tomu v Jelšovcích byl zjištěn obdélný žlab, který původně vyplňovala dřevěná břevna $\mathrm{a} v$ rozích byly doklady srubové konstrukce (Bátora 1988, 84). Tyto konstrukční prvky nám na sídlišti v Hulíně ale chybí.

\section{POH ŘEBIŠT ̌̌}

Se 101 hroby patří hulínské pohřebiště k těm rozsáhlejším. V hrobě 86 byli pohřbeni dva jedinci, jednotlivých pohřbů máme tedy dochovaných 102. $\mathrm{V}$ druhé fázi výzkumu se potvrdil předpoklad, že pohřebiště pokračuje dále pod nezkoumanou plochu objevem tří hrobů. Jeho skutečný rozměr tedy neznáme. Největším známým pohřebištěm nitranské kultury je lokalita Ludanice - Mýtna Nová Ves, kde bylo odkryto přes 500 hrobů, $\mathrm{z}$ nichž většina náležela právě nitranské kultuře (Bátora 2018, 78), na Moravě je to stále Holešov se 420 hroby (Ondráček/ Šebela 1982).

Pohřebiště bylo velice chudé, $\mathrm{z}$ celkového počtu 101 hrobů bylo 53 zcela prázdných, případně obsahovaly jen drobné zlomky keramiky. Ostatní hroby obsahovaly $\mathrm{v}$ průměru jeden až dva milodary. V nitranské kultuře se zemřelí tradičně ukládali do hrobu podle pohlaví, muži na pravý bok ve směru $\mathrm{Z}-\mathrm{V}$ a ženy na levý bok ve směru $\mathrm{V}-\mathrm{Z}$, takto byli natočeni tváŕí $\mathrm{k}$ jihu (Bátora 2018, 267). $\mathrm{V}$ případě Hulína 3 byla poloha zemřelého určitelná v 78 př́padech. Ve zbývajících 24 případech bud' ostatky v hrobech chyběly, nebo jejich poloha nebyla určitelná z důvodu špatného dochování. Na pravém boku zde bylo uloženo 48 zemřelých a na levém 30 zemřelých. $Z$ antropologické analýzy (Pankowská 2007) vyplývá, že v několika případech pohlaví symbolické neodpovídá antropologickému. $\mathrm{V}$ př́ípadě zemřelých uložených na pravém boku bylo 13 určeno jako muži, 6 jako ženy a zbylých 29 bylo neurčitelných ( $\mathrm{z}$ toho $\mathrm{v} 7$ prípadech $\mathrm{z}$ důvodu nízkého věku, zbytek nebylo možné určit kvůli špatnému stavu dochování). U polohy na levém boku bylo 10 určených jako ženy, 3 jako muži a 17 bylo neurčitelných ( $\mathrm{z}$ toho ve dvou prípadech $\mathrm{z}$ důvodu nízkého věku, zbytek nebylo možné určit kvůli špatnému stavu dochování). Celkem 9 hrobů se odchyluje od tradiční pozice, tedy 3 muži a 6 žen bylo pohřbeno v opačné poloze. Pravděpodobnost, že by hroby náležely jiné kultuře je malá, protože tvoří ucelenou skupinu. Podobný př́klad se objevuje u kultury zvoncovitých pohárů, kde se upozorňuje na zcela jinou koncepci genderu a sociální identity (Turek 2010). Známé jsou dva prŕ́klady z kultury se šňurovou keramikou, kdy byl starší muž pohřben $\mathrm{s}$ ženskou výbavou a z kultury zvoncovitých po- hárů, odkud známe hroby několika žen s bohatou mužskou výbavou (Turek 2010, 122, 123). Kromě toho se uvádí i př́iklady z etnografie, kde docházelo $\mathrm{z}$ nějakého důvodu ke změně pohlaví, př́ípadně, kde existovalo více než jen dvě pohlaví (Turek 2010).

Dalším důležitým faktorem je orientace hrobů podle světových stran. $\mathrm{V}$ případě hulínského pohřebiště převažovala orientace ve směru SZ-JV $\mathrm{v}$ př́padě pohřbů na pravém boku a JV-SZ u pohřbů na levém boku. Další variantou byla orientace ve směru SSZ-JJV a JJV-SSZ. Vzácněji se objevila i orientace $S-J$ a J-S, která je pro nitranskou kulturu nejméně vlastní, přesto ale není zcela neobvyklá (Bátora 1991, 119). Tato orientace je naopak typická pro únětickou kulturu (Bátora 2018, 267), ale žádné další potenciální vlivy únětické kultury se na pohřebišti neobjevují.

Hrobové jámy byly mělké. Převažujícím tvarem byl obdélný se zaoblenými rohy. V několika případech se vyskytly i hrobové jámy oválného tvaru. Jámy byly jednoduché, vanovitého řezu s kolmými stěnami a plochým dnem. Mezi hroby se nacházelo několik kůlových jam, ale ty netvořily žádnou strukturu. Nelze vyloučit, že zde došlo k narušení nějakého staršího sídliště, tomu by nasvědčovalo i seskupení tři kůlových jam v řadě. Zbytek mohl zaniknout $\mathrm{v}$ důsledku husté koncentrace hrobů.

Pro nitranskou kulturu je typické i sekundární otvírání hrobů at už z důvodů vykrádání, nebo $z$ důvodů rituálních. Dokumentace hulínského pohřebiště bohužel nezachycuje hroby v detailu, takže přímý doklad narušené výplně nemáme ani v ploše ani na profilu. $V$ několika hrobech máme dislokované ostatky, které by mohly nasvědčovat právě druhotnému narušení hrobů. Většina byla v terénu přičtena činnosti hlodavců. Jediný hrob, který byl prokazatelně narušený, byl hrob 48 , kde lebka zemřelého muže spočívala na břiše, tváří směřující dolů. K oddělení lebky muselo dojít po částečném rozložení měkkých tkání, protože dolní čelist je na svém místě. Př́ipady rituálního narušení hrobů se objevily na pohřebištích v Příkazech a v Branči, kde bylo záměrné oddělení potvrzeno zářezy na kostech. J. Bátora to interpretuje jako strach z návratu mrtvých (Bátora 1991, 126). Stav dochování kostí v našem př́ípadě podobné zjištění neumožňuje. Další možností narušení hrobů jsou superpozice. Ty se vyskytly u hrobů 62,92 a 93 . V hrobě 62 bylo uloženo dítě ve věku 9-10 let na pravém boku, $v$ hrobě 92 byl jedinec ve věku 40-55 let uložený na pravém boku a v hrobě 93 byl jedinec ve věku 18-22 let také na pravém boku. Dále u hrobů 52, 55 a 63 . V hrobě 52 leželo na pravém boku dítě ve věku $4-5$ let, $v$ hrobě 55 muž ve věku 40-57 let uložený také na pravém boku a v hrobě 63 muž na pravém boku ve věku 35-40 let. Další hroby v superpozici byly hroby 57 
a 61 . V obou byli jedinci uloženi na pravém boku, v hrobě 57 byl jedinec ve věku 18-22 let a v hrobě 61 ve věku 30-55 let, ani v jednom případě není pohlaví určitelné. V hrobě 44 byla uložena žena na levém boku ve věku 30-35 let a v superpozici byl hrob 49, kde bylo na pravém boku uloženo přibližně tříleté dítě. Další byla superpozice tří hrobů 79, 81 a 82. V hrobě 79 nebyly dochované lidské ostatky a byl silně narušen zbývajícími dvěma. $V$ hrobě 81 ležel na pravém boku muž starší 20 let a v hrobě 82 byly dochované pouze zlomky lebky dítěte ve věku přibližně 3 let. Dokumentace hrobů nám neumožňuje přesnější interpretaci stratigrafických vztahů jednotlivých superpozic. Ve čtyřech z celkových pěti případů bylo v jednom $\mathrm{z}$ hrobů uloženo dítě, což by mohlo značit na záměr pohřbít dítě s rodiči nebo př́buznými. K tomu máme ještě hrob 86 , kde byli dva dospělí muži pohřbeni v jedné jámě. Pohřby ale nebyly současné, první jedinec byl pohřben ve vlastní hrobové jámě a později byl druhotně do dolní části stejné jámy uložen druhý, silně skrčený jedinec.

Možnosti antropologického zkoumání souboru byly omezené, protože většina koster byla ve špatném stavu. Z první etapy pocházelo celkem 98 hrobů, z nichž 84 obsahovalo lidské ostatky. Ani další 3 hroby z druhé etapy vzhledem k silnému narušení technikou neumožnily podrobnější analýzu. Z celkového počtu 84 ostatků se podařilo zjistit pohlaví pouze u 34 jedinců, a to $\mathrm{z}$ důvodu dochovaní nebo nízkého věku. $Z$ toho bylo 16 určeno jako ženských a 16 jako mužských (Pankowská 2007, 4).

Věk se podařilo určit u 72 jedinců $\mathrm{z}$ celkového počtu 102. Vzhledem k často fragmentárnímu sta- vu dochování se u mnoha ostatků podařilo určit věkovou kategorii pouze obecně. Z celkového počtu náleželo 10 sad ostatků dětem a zbytek byli dospělí v různých věkových kategoriích (tabela 1; věkové kategorie určeny dle Dobisíková 1999, 236).

$\mathrm{Na}$ dvou sadách ostatků byla nalezena tzv. spondylosis deformans, což je artrotická změna projevující se srůstem obratlů (Pankowská 2007, 11). Srůst hrudních obratlů byl zaznamenán u ženských ostatků z hrobu 5 a ostatků juvenilního jedince z hrobu 17. U stejných jedincủ byl zaznamenán i epigenetický znak v podobě tzv. sutura metopica (Pankowská 2007, 19). To samozřejmě může naznačovat, že se jednalo o př́ibuzné.

\section{KERAMIKA}

Nálezy keramiky v nitranských hrobech představují spíše ojedinělý jev. A. Točík uváděl, že keramika se vyskytuje v přibližně 10-15\% nitranských hrobů (Točík 1963, 756). V Hulíně byly keramické nádoby pouze ve 4 hrobech. $Z$ těchto čtyř se $\mathrm{k}$ laboratornímu zpracování dostaly pouze dvě, zbývající jsou zaznamenané pouze v dokumentaci. Zlomky keramiky se objevují i v zásypech hrobů, někdy i na úrovni pohřbu. Výskyt keramických zlomků v zásypu hrobu je zmiňován i J. Ondráčkem (1993, 260). V našem případě byly zlomky keramiky v 16 hrobech. Nejvyšší počet zlomků byl 7, průměrně se ale jednalo o 1-3. Většina byla atypická, pouze v hrobě 19 se nacházel zlomek hrdla, v hrobě 32 zlomek dna a v hrobě 74 drobný zlomek zdobený dvojitým otiskem šňůry.

Tabela 1. Hulín 3-U Potůčku. Zastoupení jednotlivých věkových kategorií a pohlaví na pohřebišti.

\begin{tabular}{|c|c|c|c|c|}
\hline & Počet jedinců & Muži & Ženy & Neurčiteln \\
\hline Infans I & 6 & - & - & 6 \\
\hline Infans II & 4 & - & - & 4 \\
\hline Juvenis & 4 & - & - & 4 \\
\hline Juvenis/Adultus I & 8 & - & 3 & 5 \\
\hline Adultus I & 6 & 4 & - & 2 \\
\hline Adultus I/Adultus II & 3 & - & 1 & 2 \\
\hline Adultus II & 15 & 5 & 6 & 4 \\
\hline Adultus II/Maturus I & 5 & 3 & - & 2 \\
\hline Maturus I & 7 & 2 & 1 & 4 \\
\hline Maturus I/Maturus II & 3 & 1 & 1 & 1 \\
\hline Maturus II & 3 & - & 1 & 2 \\
\hline Maturus II + & 4 & - & - & 4 \\
\hline Dospělý jedinec & 4 & - & 4 & - \\
\hline
\end{tabular}




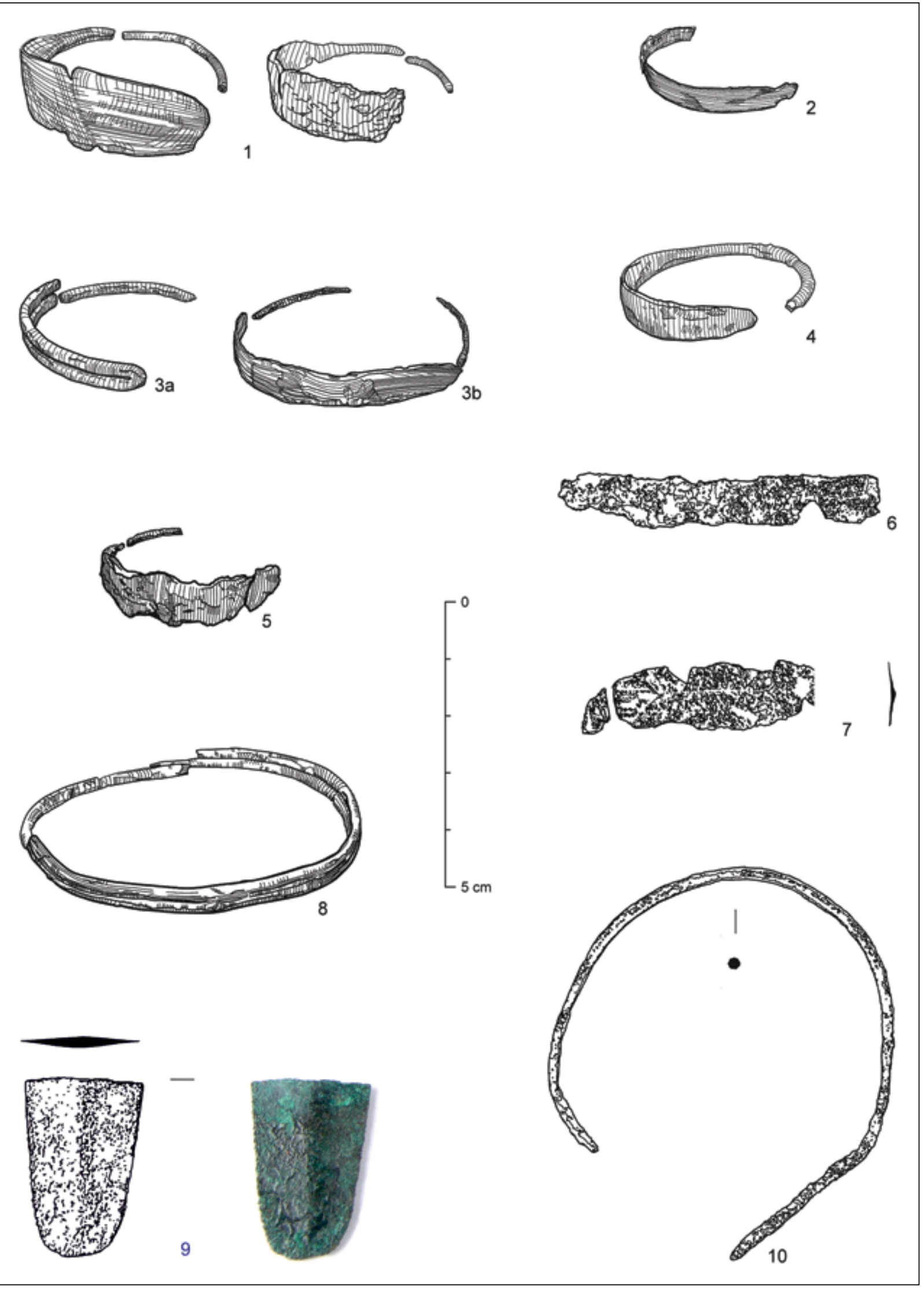

Obr. 3. Hulín 3-U Potůčku. 1-5, 8-kruhové ozdoby ve tvaru vrbového listu nebo z dvojitého drátu; 6-7 - nožíky ve tvaru vrbového listu; 9 - část dýky; 10 - náramek (kresby E. Schimerová). 


\section{Hrnky}

Ze čtyř nádob se dvě dochovaly pouze $\mathrm{v}$ dokumentaci, to byl př́pad i menšího hrnku z hrobu 57 (obr. 2: 4). Nádoba, nejspíše bez výzdoby, se nacházela v mužském hrobě těsně pod koleny zemřelého. Profilace je esovitá a pozvolná. Vzhledem k tomu, že je nádoba focená v bloku hlíny, je pravděpodobné, že ouško je skryté v něm.

Další fragment hrnku pochází z ženského hrobu 74 (obr. 2: 3). Nádobka ležela nad lebkou, byla velmi poškozená a nepodařilo se ji plně rekonstruovat. Materiál je barevně nerovnoměrný, přechází od světle hnědé po tmavě hnědou. Stejně jako všechny ostatní nádobky má svrchní vrstvu z jemně plavené hlíny, která se loupe. Vlastní jádro je ostřené drobnými kamínky. Přestože se nedochovalo ouško, předpokládáme, že nádobka ho původně měla. Podobné tvary hrnků jsou pro nitranskou kulturu typické, a jsou dobře dokumentované např́íklad na pohřebišti v Holešově (Ondráček/Šebela 1985). Na hrdle nádobky jsou rýhy, ale není jednoznačné, zda se jedná o pozůstatky výzdoby.

\section{Džbánek}

Džbánek se nacházel v hrobě 65 , kde nebyly dochované ostatky. Povrch nádoby je pokryt jemnou, hladkou hlínou tmavě hnědé barvy (obr. 2: 2). V místech, kde byla svrchní vrstva odloupnutá, bylo jádro ostřené drobnými kamínky. Celý povrch nádoby včetně ucha byl zdoben dvojitými otisky šňůry. Tento typ nádoby je svým tvarem, ale především výzdobou, typický pro starší nitranskou kulturu. Pro řazení do starší fáze hovoří také distribuce výzdoby. Hrdlo je zdobeno horizontálními a tělo vertikálními otisky šňưry, což je charakter výzdoby příznačný pro starší nitranskou (resp. mierzanowickou) kulturu (Kadrow/Machnik 1997, 180).

\section{Nádobka z hrobu 79}

V hrobě 79 se nenašly lidské ostatky. Hrob byl $\mathrm{v}$ superpozici s hroby 82 a 83 . Nádoba je zdokumentovaná pouze na fotografii (obr. 2: 5), ze které není možné mnoho zjistit.

\section{MĚDĚNÉ ARTEFAKTY}

Kovové artefakty jsou označeny jako měděné, přestože se nepodařilo provést analýzu jejich složení. Tento předpoklad vychází z faktu, že na nitranských pohřebištích, kde byla provedena analýza jako je Holešov, Slatinice nebo Jelšovce, se bronzové předměty nevyskytují (Bátora 2000; Ondráček/Šebela 1985; Šmíd 2006). Měděné předměty byly dochované ve velice fragmentárním stavu a bylo obtížné určit, zda se jedná o více předmětů, nebo jen zlomky jednoho.

\section{Šperky a nožíky ve tvaru vrbového listu}

Šperky a předměty ve tvaru vrbového listu představují nejcharakterističtější předmět pro nitranskou kulturu. Jsou dědictvím kultury Chłopice-Veselé (Budinský-Krička 1965, 95; Točík 1963, 746). Jedná se o předmět, jehož jedna polovina je ze zašpičatělého drátu a druhá je roztepaná do tvaru listu (Točík 1963, 746). Starším typem je menší hladký list, mladší jsou potom se zesíleným středovým žebrem (Bátora 2018, 171; Budinský-Krička 1965, 95; Točík 1963, 746). Kromě vrbových listů stočených do kruhu, které sloužily jako šperky, známe i ploché varianty, které sloužily pravděpodobnějako nožíky a vzácněji jako jehlice (Vladár 1971, 95). Na Slovensku se jich nachází mnohem více než na Moravě, což někteři autoři přičítají rozdělení na dvě samostatné skupiny (Benkovsky-Pivovarová 1998, 146), nebo př́padně různé intenzitě lokálních vlivů (Točík 1963, 748).

Tento šperk je v Hulíně zastoupen celkem v 6 př́padech $\mathrm{v}$ téměř kompletní podobě. Menší zlomky kruhových šperků byly zachyceny ve 3 hrobech. Ve dvou př́ípadech můžeme uvažovat i o pozůstatcích nožíku ve tvaru vrbového listu. Všechny exempláře jsou hladké, pouze u jednoho je patrné zesílené středové žebro.

V ženském hrobě 19 se nacházely dva kruhové šperky ve tvaru vrbového listu, každý byl uložen na jednom spánku (obr. 3: 1). Další o něco menší a robustnější šperk ve tvaru vrbového listu byl uložen také na spánku ženy v hrobě 58 (obr. 3: 4). Další dva méně dochované byly v hrobech 43 (obr. 3: 2) a 50 (obr. 3: 3b). Hrob 43 patřil asi pětiletému dítěti, které bylo uloženo na pravém boku. Šperk byl dochovaný ve dvou zlomcích bez jehly. V ženském hrobě 50 se kromě zlomků kruhového šperku dochovaly ještě dva samostatné zlomky jehly. Poslední šperk ve tvaru vrbového listu, který byl nalezen relativně vcelku, je z ženského hrobu 70 (obr. 3: 5). Další šperky už byly velmi silně zkorodované. Jejich pozůstatky se našly v mužském hrobě 41 , mužském hrobě 48 a ženském hrobě 60.

Ve dvou případech se vyskytly i potenciální nožíky. První nožík byl v mužském hrobě 57 (obr. 3: 6), kde se nacházel u pánve. V hrobě 88 spočívala žena, uložená ovšem na pravém boku. Nožík ležel také u pánve (obr. 3: 7). Tento jediný měl patrné zesílené středové žebro, které by mělo být typologicky 
A

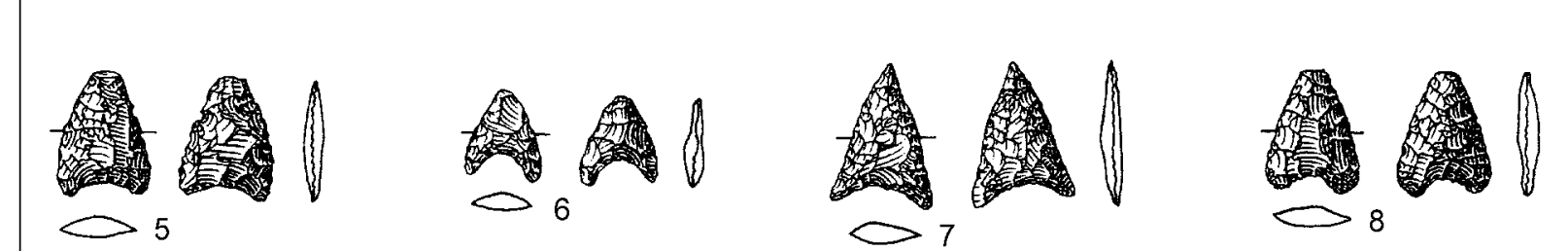

A

0 
mladší (Točík 1963, 750). Oba byly silně zkorodované a jejich původní tvar je neznámý.

Sperky ve tvaru vrbového listu se na pohřebišti vyskytly jak $\mathrm{v}$ mužských (3 př́pady, z toho jeden bylo dítě), tak v ženských hrobech (6 př́ípadů). Nožíky byly pouze $\mathrm{u}$ jedinců pohřbených na pravém boku.

\section{Ozdoby z dvojitého drátu}

Ve většině prrípadů se jednalo o zlomky, pouze ve dvou př́padech se dochovaly pozůstatky kruhových ozdob z dvojitého drátu. První byla v hrobě 50, společně se šperkem ve tvaru vrbového listu (obr. 3:3a), kde spočívala na pravém spánku. Druhý šperk byl v mužském hrobě 66 (obr. 3: 8).

\section{Drátěný náramek}

Jediný náramek byl v mužském hrobě 57 a byl navlečený na zápěstí (obr. 3: 10). Tento typ ozdoby je poměrně častý na pohřebišti v Holešově (Ondráček/ Šebela 1985). A. Točík tomuto druhu ozdob přikládá domácí původ (Toč́́k 1963, 772).

\section{Měděné trubičky}

Celkem 4 trubičky ze svinutého plechu byly v ženském hrobě 46. Dvě byly na boční straně lebky v horních partiích a další dvě byly pod dolní čelistí společně s těsně přiléhajícím kostěným korálkem.

Měděné trubičky, at' už plechové nebo svinuté $z$ drátu, se v nitranské kultuře vyskytují běžně, a to často v kombinaci s korálky z dalších materiálů, jako je kost/paroh nebo fajáns (Ondráček 1993, 259, 260).

\section{Zlomek dýky}

Tento předmět se nacházel v inventáři hrobu 53, který patřil muži (obr. 3: 9). Podobné artefakty byly nalezeny i v Holešově, např́klad v hrobech 10 a 120. Autoři ještě uvádí zlomek litého kopí z hrobu 174, které se našemu zlomku také podobá (Ondráček/ Šebela 1985, tab. 2; 13; 19).

\section{Ostatní drátěné ozdoby a zlomky plechu}

Sem řadíme ty nálezy, které vzhledem ke stavu dochování nešlo zařadit do žádné z kategorií. Všechny drátky byly zahnuté, takže pravděpodobně byly bud' zbytky kruhových ozdob, nebo jehly odlámané z vrbových listů. Různé zlomky drátu byly celkem v 8 hrobech. Drobné plíšky byly ve 3 hrobech.

\section{ŠTÍPANÁ INDUSTRIE}

Početně patří štípaná industrie $\mathrm{k}$ nejvíce zastoupeným artefaktům. Celkem bylo nalezeno 41 kusů. Nálezů bylo více, ale některé jsou zaznamenané pouze v dokumentaci. Nejčastěji jsou zastoupeny úštěpy, ve větší míře i šipky, dále zlomky čepelek, škrabadla a hroty. Nejdůležitějším artefaktem je bezesporu silicitová dýka. Analýzu a vyhodnocení celého souboru provedl Antonín Přichystal (2013).

\section{Suroviny}

Z celkového počtu 41 kusů, 24 náleží silicitu glaciálních sedimentů, 6 kusů je ze silicitu krakovsko-čenstochovské jury A, 3 byly určeny jako Krumlovský les I, po 2 kusech bylo ze silicitu krakovsko-čenstochovské jury bez bližšího určení a červeného radiolaritu se zelenými žilkami. Po jednom kusu je pak ze silicitu krakovsko-čenstochovské jury $C$ nebo E, šedého radiolariového rohovce, moravského jurského rohovce a přepáleného silicitu s reliktem černé kůry (Přichystal 2013, 1, 2).

\section{Šipky}

Na pohřebišti bylo celkem 10 šipek, a to v hrobech 8 (rohovec typu Krumlovský les I; obr. 4: 1), 42 (silicit krakovsko-čenstochovské jury, varieta A; obr. 4: 2), 56 (silicit krakovsko-čenstochovské jury, varieta A; obr. 4:3), 63 (rohovec typu Krumlovský les I; obr. 4: 4), 76 (šedý radiolariový rohovec; obr. 4: 5), 83 (petrosilex, patrně z SGS a patinovaný silicit; obr. 4: 6, 7), 86 (silicit krakovsko-čenstochovské jury, varieta A; obr. 4: 8), 90 (moravský jurský rohovec; obr. 4: 9) a 92 (červenohnědý radiolarit se zelenými žilkami; obr. 4: 10). Kromě hrobu 83, kde byly šipky dvě, byly vždy v hrobech po jedné. U hrobu 83 bylo zajímavé to, že jedna byla nalezena mezi obratli a druhá při zpracování uvnitř lebky (obr. 4: 6, 7). Nebylo však zjištěno žádné zranění na kostech, které by ukazovalo na násilnou smrt (Pankowská 2007, 75). Bez traseologické analýzy nejsme schopni určit, zda šipka mohla způsobit zranění nebo smrt daného jedince. Šipky jsou typické pro starší fázi nitranské kultury, běžné jsou i v předcházející kultuře Chłopice-Veselé, v klasické fázi nitranské kultury jejich výskyt upadá a $\mathrm{v}$ přechodné už $\mathrm{v}$ podstatě mizí (Bátora 1991, 103). Všech devět hrobů dle polohy náleželo mužům. $Z$ antropologického hlediska bylo 


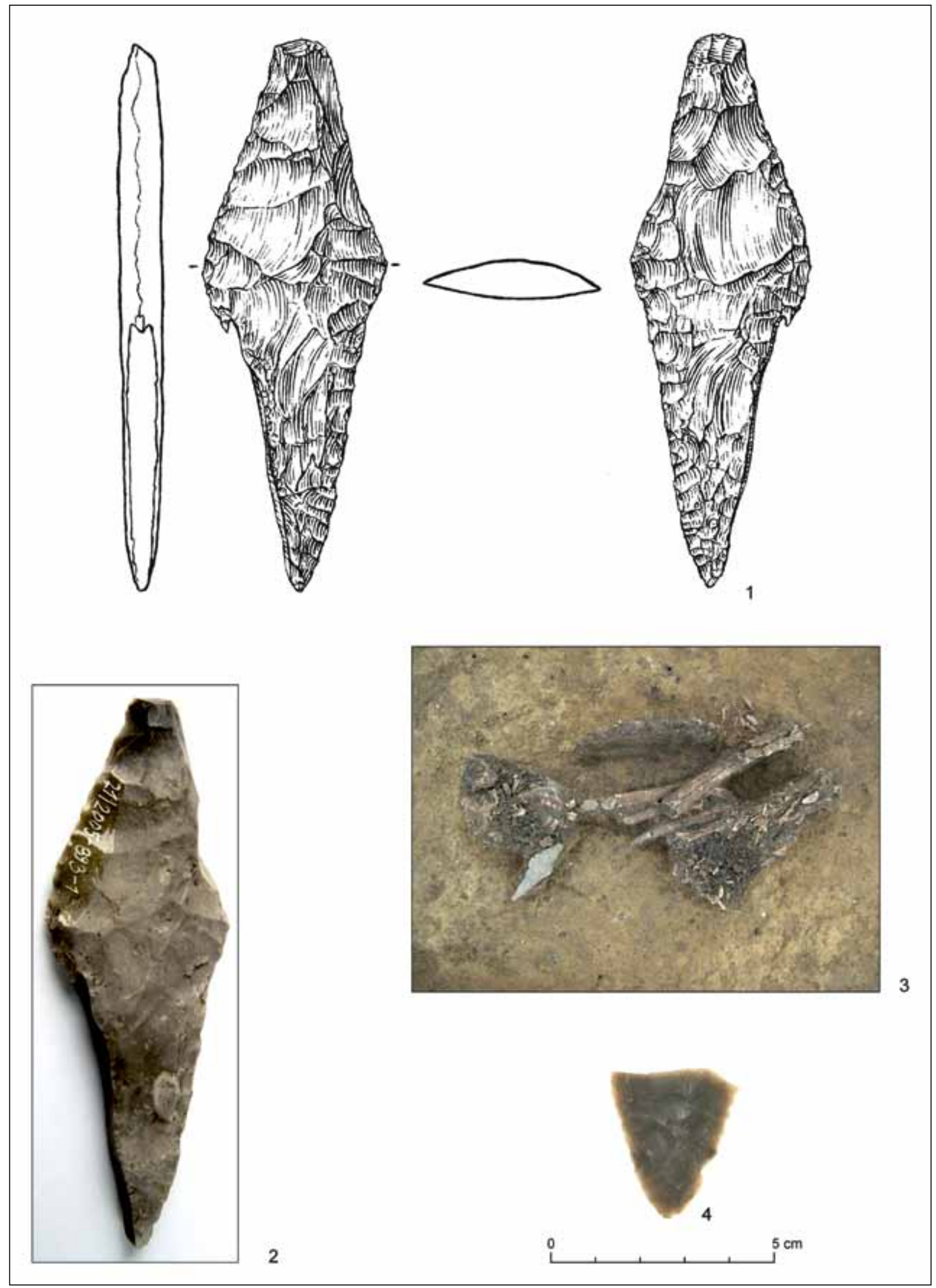

Obr. 5. Silicitové dýky. 1, 2 - Hulín 3-U Potůčku, hrob 93 (kresba B. Ludikovská, foto M. Bém); 3 - Hulín 3-U Potůčku, hrob 93, dýka in situ (foto T. Berkovec); 4 - Hulín 1, objekt 186, fragment dýky (foto E. Schimerová). 
pohlaví ve 4 př́padech mužské, ve 4 prrípadech nešlo určit a v jednom př́ípadě bylo ženské.

\section{Dýka}

Nález silicitové dýky z mužského hrobu 93 byl tím nejzajímavějším, co hulínské pohřebiště přineslo (obr. 5: 1,2). Tato dýka je v nitranské kultuře první stratifikovaný nález svého druhu. Dýky jsou z lokalit náležejících nitranské kultuře známé, ale dosud žádná nebyla zachycena v kontextu. Dýky pocházejí z lokalit Kúty, Plavecké Podhradie, Dolný Lopašov, Zlín, Určice a Mistřice (Bátora 1991, 98). Dosud nepublikovaný je nález zlomku dýky pocházející ze sídlištního objektu nitranské kultury číslo 186 z lokality Hulín 1 (obr. 5: 4). Dýka byla vyrobena se silicitu glaciálních sedimentů severského původu, dánského stáří (Přichystal 2013, 1). Uložena byla do hrobu již poškozená, celá jedna strana byla ulomená, patrně po nárazu na tvrdý povrch. Je otázkou, zda lze toto poškození dávat do souvislosti $\mathrm{s}$ uložením $\mathrm{v}$ hrobu. Jejich nízký počet značí, že tento typ artefaktu byl v této době vzácný.

\section{Ostatní štípaná industrie}

Většina štípané industrie byla tvořena úštěpy, kterých bylo 17, př́ipadně ještě rezidui jader. Mezi částečné polotovary bychom mohli zařadit ještě dva retušované úštěpy. $Z$ nástrojů byly dále zastoupené hroty, škrabadla a čepele.

\section{BROUŠENÁ INDUSTRIE}

Soubor čítá pouze pět předmětů. Tři nátepní destičky, jeden sekeromlat a predmět, který byl pracovně nazván jako miniatura sekeromlatu.

\section{Nátepní destičky}

Nátepní destičky pocházely z hrobů 4, 53 a 56. Všechny tři hroby byly mužské. Destičky z hrobů 4 (obr 4: 12) a 56 (obr. 4: 14) byly vyrobeny z křemenného pískovce s glaukonitem a muskovitem (Přichystal 2013, 1, 2). Destička z hrobu 53 (obr. 4: 13) byla vyrobena ze silně vápnitého tufitického prachovce (Přichystal 2013, 1, 2). Typicky mají nitranské nátepní destičky jeden provrt na každé straně. Destička z hrobu 56 je nedokončená, s naznačeným provrtem jen na jedné straně. Destička v hrobě 4 byla umístěna na pravé ruce, těsně nad loktem.
Destička v hrobě 53 byla mírně dislokovaná, ale původně byla zřejmě umístěná identicky. $V$ hrobě 56 byla destička mimo ostatky nalevo od zemřelého. Všechny destičky jsou velice drobné, prachovcová je tenká a křehká. Často se zvažuje, že destičky byly součástí nátepníku vyrobeného s největší pravděpodobností z organického materiálu, čímž se vysvětluje i absence jednoho nebo obou otvorů (Bátora 2018, 212; Turek 2010, 61).

\section{Sekeromlat}

Sekeromlat se na pohřebišti našel pouze jeden v mužském hrobu 42, nedaleko od pravého boku zemřelého. Je vyroben ze silně patinovaného olivinického bazaltu (Přichystal 2013) a je rombického tvaru s provrtem umístěným nesymetricky blíže ke straně (obr. 4: 15). Nelze vyloučit, že byl do tohoto tvaru druhotně přepracovaný.

Nálezy sekeromlatů jsou v nitranské kultuře známé, především $\mathrm{v}$ její starší fázi se vyskytovaly v mužských hrobech (Bátora 2018, 212). Podobné sekeromlaty pocházejí z lokality Čierny Brod z hrobu 65 (Veliačik 1969, 305, obr. 4), a také z hrobu náčelníka číslo 262 z Mýtné Nové Vsi (Bátora 1991, 102).

\section{Miniatura sekeromlatu}

Předmět, který je označen jako miniatura sekeromlatu, není broušenou industrií v pravém smyslu. Jedná se o neopracovaný valounek křemenného pískovce (Přrichystal 2013, 1, 2), který má na jedné straně vyrytý kruh, díky čemuž v kombinaci s jeho tvarem prripomíná malý sekeromlat (obr. 4: 11). Byl jediným artefaktem $\mathrm{v}$ hrobu 30 . Vzhledem ke stavu dochování zde nebylo možné zjistit ani věk ani polohu zemřelého.

V kontextu samotné nitranské kultury se jedná o ojedinělý nález. Nejbližší analogie v rámci starší doby bronzové jsou miniaturní kamenné sekeromlaty z jihočeského hradiště Dívčí Kámen, které byly vyrobeny $\mathrm{z}$ hadce a byly interpretovány jako dětské hračky (Poláček 1966, 28). Účel předmětu je nejednoznačný, pokud by se našel mimo kontext, pravděpodobně by zůstal nepovšimnutý.

\section{KOSTĚNÉ A PAROHOVÉ ARTEFAKTY}

Předměty z kosti/parohu, nebyly nijak variabilní. Většinu představovaly válcovité korálky, kromě toho se našly ještě dva zahrocené nástroje. Stav dochování byl, stejně jako u lidských kostí, velice špatný, patrně vlivem půdních podmínek. 


\section{Kostěné a parohové korálky}

Počet korálků v hrobech byl poměrně nízký a nacházely se v 16 hrobech. Z jiných lokalit nitranské kultury je zastoupení korálků $\mathrm{v}$ hrobech značné, $\mathrm{v}$ Holešově dosahoval jejich počet $\mathrm{v}$ některých hrobech přes 300 kusů (Ondráček/Šebela 1985). Celkový počet je těžké odhadnout vzhledem $\mathrm{k}$ jejich fragmentarizaci. Nejvyšší počet byl v ženském hrobě 60, kde jich bylo 44 a k tomu 13 drobných zlomků. Většina se nacházela v oblasti nad pánví u bederních obratlů. Druhý nejvyšší počet byl 31 celých a 35 zlomků z ženského hrobu 15. Korálky se nacházely u pravého lokte $v$ místě ohnutých a přitažených paží. V dalším ženském hrobu číslo 58 bylo 23 korálků, z toho $9 \mathrm{u}$ pravé lopatky a $14 \mathrm{v}$ prostoru mezi stehenními a holenními kostmi. Několik korálků bylo stále seřazeno v řadě. $V$ ženském hrobě 19 bylo 19 korálků. Původní poloha korálků v hrobě je nejasná, několik jich bylo roztroušených pod levou stehenní kostí. V ženském hrobě 50 bylo nalezeno 12 korálků. Ve zbývajících hrobech počet korálků kolísal v rozmezí jeden až pět.

Korálky tedy pochází z celkem 16 hrobů, kdy v 15 př́padech se jedná o hroby ženské. Výjimku představoval hrob 1, kde dle antropologického určení byla uložená žena, ale na pravém boku a hrob 40, kde byl pro změnu muž, ale na levém boku.

Kostěné korálky se $\mathrm{v}$ nitranských hrobech objevují poměrně běžně jako součásti náhrdelníků, ale také jako ozdoba oděvu v podobě lemování, či třásní (Furmánek/Veliačik/Vladár 1991, 238). U náhrdelníků se nachází často v kombinaci s dalšími materiály, jako s měděnými trubičkami nebo fajánsovými korálky (Furmánek/Veliačik/Vladár 1991, 238). $\mathrm{V}$ našem př́padě se podoba korálkových aplikací dá rekonstruovat jen těžko, protože jejich počet je nízký a jen několik jich bylo nalezeno $\mathrm{v}$ řadě. $\mathrm{V}$ každém př́padě u korálků nalezených na hrudi a v horní části těla obecně se dá předpokládat, že se jedná o náhrdelník. Mnoho korálků bylo nalezeno v okolí pánve, kde se dá uvažovat spíš o oděvních aplikacích. Nelze ovšem vyloučit ani jejich uložení v organickém váčku, nebo vložení náhrdelníku do hrobu na toto místo.

\section{Kostěné nástroje}

Různé hroty a šídla se vyskytují poměrně často, nicméně $\mathrm{v}$ našem př́padě se vyskytly pouze dva zahrocené nástroje z kosti, a to v hrobech 48 a 53. $\mathrm{V}$ porušeném hrobě 48 ležel kostěný hrot $\mathrm{v}$ místě dislokované lebky.

\section{CHRONOLOGIE}

Datace celého pohřebišš̌jen na základě artefaktů je vzhledem k jejich množství nemožná. Pro dataci máme k dispozici milodary jako keramika zdobená šňroovou výzdobou po celém povrchu, industrii ve tvaru vrbového listu s hladkým listem, nátepní destičky, šipky a kostěné korálky, a ty byly tradičně kladeny do starší fáze (Ondráček 1972, 170). Stejně tak sekeromlat, nebo kamenná dýka. Dříve byly brány jako chronologicky mladší drátěné šperky a měděné dýky, které se považovaly za vliv nastupující únětické kultury (Ondráček 1972, 170). Na pohřebišti v Jelšovcích se ale ukázalo, že i artefakty, které byly původně považované za mladší, jako industrie ve tvaru vrbového listu se středovým žebrem, ozdoby z dvojitého drátu a měděné dýky, se vyskytly ve skupině hrobů, která je řazena do fáze starší nitranské kultury označené jako stupeň Jelšovce I (Bátora 2000, 513). Nelze ani vyloučit př́slušnost některých hrobů do klasické fáze nitranské kultury, která byla J. Bátorou vydefinována do dvou fází - IIa a IIlb. Žádné vlivy únětické kultury v rámci samotné hmotné kultury, které jsou tolik patrné na pohřebišti v Holešově, se zde nenachází. To může být ale dáno chudou výbavou na pohřebišti. $\mathrm{V}$ př́ípadě mierzanowické kultury se navíc upozorňuje na to, že přechody jednotlivých fází se velice těžko sledují, a je třeba dbát především na frekvenci výskytu jednotlivých artefaktů (Kadrow/Machnik 1997, 179).

Z hrobů 4, 5, 47, 48, 53, 66 a 73 (obr. 1:4) se podařilo získat radiokarbonová data (viz Peška/Tajer 2015, 97). Ta v zásadě potvrzují to, co ukazují i artefakty, tedy že na pohřebišti jsou zastoupeny hroby jak starší, tak klasické fáze nitranské kultury. Datovatelné nálezy byly $\mathrm{v}$ hrobech 4 (reziduum jádra a nátepní destička), 48 (zbytky hladkého kruhového šperku ve tvaru vrbového listu a kostěný hrot), 53 (dva úštěpy, kostěný nástroj a nátepní destička) a 66 (ozdoba z dvojitého drátu). Jinak byly hroby prázdné, nebo obsahovaly zlomky keramiky. V př́padě hrobu 73 se vyskytly ještě 2 kostěné korálky.

\section{ZÁVĚR}

Objevení dalšího nitranského pohřebiště, navíc společně s pozůstatky sídliště v okolí Hulína, doplňuje obraz nitranského osídlení v tomto regionu. V tuto chvíli máme $\mathrm{z}$ dané oblasti zachyceno 7 poloh (Peška/Tajer 2015, 80). Sídliště náležející nitranské kultuře bylo objeveno i na lokalitě označené jako Hulín 1, J. Peška ho datoval na počátek časné mierzanowické fáze (Berkovec/Peška 2005, 48). Kromě 
toho se zde našly ještě hroby, které tvořily menší skupinku. Stejně jako v našem př́padě byly hroby skromně vybavené a náležely také starší fázi (Berkovec/Peška 2005, 48). Další osídlení nitranské kultury bylo zdokumentováno i na dalších lokalitách v okolí (viz Peška/Tajer 2015). Vyhodnocení samotného souboru s sebou neslo jisté obtíže, nebot jak bylo zmíněno $\mathrm{v}$ textu, některé nálezy se nedochovaly a dokumentace byla v některých prrípadech neúplná nebo $\mathrm{v}$ rozporu. I presto přináší tato lokalita významné poznatky, a to nejen díky objevu sídlištních situací, ale také díky výskytu některých součástí hrobové výbavy, se kterými jsme se v nitranské kultuře dosud nesetkali.

\section{LITERATURA}

Bátora 1988 - J. Bátora: Najnovšie poznatky o pohrebnom ríte ludu nitrianskej skupiny. In: M. Dočkalová (ed.): Antropofagie a pohřební ritus doby bronzové. Materiály z pracovního setkání Brno, pavilon Anthropos 24.25. 10. 1988. Brno 1988, 83-90.

Bátora 1991 - J. Bátora: The relection of economy and social structure in the cemeteries of the Chłopice-Veselé and Nitra culture. Slovenská archeológia 39, 1991, 91-142.

Bátora 2000 - J. Bátora: Das Gräberfeld von Jelšovce/Slowakei. Ein Beitrag zur Frühbronzezeit im nordwestlichen Karpatenbecken. Teil I-II. PAS 16/1-2. Kiel 2000.

Bátora 2018 - J. Bátora: Slovensko v staršej dobe bronzovej. Bratislava 2018.

Benkovsky-Pivovarová 1998 - Z. Benkovsky-Pivovarová: Zum Begriff Nitra-Gruppe bzw. Kultur. Pravěk NǨ 8, 1998, 141-150.

Berkovec 2007 - T. Berkovec: Nálezová zpráva ze záchranného archeologického výzkumu Hulín 3 „U Potǔčku“. Rukopis uložen v Archeologickém centru Olomouc. Olomouc 2007.

Berkovec/Peška 2005 - T. Berkovec/J. Peška: Starobronzová sídliště a pohřebiště v Hulíně - U Isidorka. Ročenka Archeologického centra Olomouc za rok 2004, 2005, 44-67.

Budinský-Krička 1965 - V. Budinský-Krička: Gräberfeld des späten schnurkeramischen Kultur in Veselé. Slovenská archeológia 13, 1965, 51-106.

Dobisíková 1999 - M. Dobisíková: Určování věku. In: M. Stloukal a kol.: Antropologie. Př́ručka pro studium kostry. Praha 1999, 235-339.

Furmánek/Veliačik/Vladár 1991 - V. Furmánek/L. Veliačik/ J. Vladár: Slovensko v dobe bronzovej. Bratislava 1991.

Hendrychová/Kočár 2007 - L. Hendrychová/P. Kočár: Hulín 3: Nálezová zpráva o archeobotanické analýze. Nepublikovaný rukopis, 2007.

Kadrow/Machnik 1997 -S. Kadrow/J. Machnik: Kultura mierzanowicka. Chronologia, taksonomia i rozwój przestrzenny. Prace komisji archeologicznej 29. Kraków 1997.

Ondráček 1972 - J. Ondráček: Pohřebiště nitranské skupiny v Holešově. Archeologické rozhledy 24, 1972, 168-172.

Rukopis přijat 5. 6. 2020

Translated by Eva Schimerová
Ondráček 1993 - J. Ondráček: Nitranská skupina. In: V. Podborský a kol.: Pravěké dějiny Moravy. Vlastivěda moravská. Země a lid. Nová řada 3. Brno 1993.

Ondráček/Šebela 1985 - J. Ondráček/L. Šebela: Pohřebiště nitranské kultury v Holešově (katalog nálezů). Studie muzea Kroměřížska 85. Kroměříž 1985.

Pankowská 2007 - A. Pankowská: Antropologická zpráva Hulín 3 „U Potůčku“. Nepublikovaný rukopis, 2007.

Peška/Tajer 2015 - J. Peška/A. Tajer: Problematika epišňůrových sídlišṫ na Moravě - stav poznání. In: J. Bátora/ P. Tóth (ed.): Ked' bronz vystriedal med'. Zborník príspevkov z 23. medzinárodného sympózia "Staršia doba bronzová v Čechách, na Moravě a na Slovensku“, Levice, 8.-11. októbra 2013. Nitra - Bratislava 2015, 77-104.

Poláček 1966 - J. Poláček: Dívčí kámen - Hradiště z doby bronzové. České Budějovice 1966.

Přichystal 2013 - A. Přichystal: Petrografický rozbor kamenných artefaktů z lokality Hulín 3. Nepublikovaný rukopis, 2013.

Schimerová 2014 - E. Schimerová: Sídliště a pohřebiště nitranské kultury v Hulíně 3. Diplomová práce. Univerzita Komenského v Bratislave. Bratislava 2014. Nepublikované.

Šmíd 2006 - M. Šmíd: Pohřebiště nitranské skupiny ze Slatinic, okres Olomouc. Slovenská archeológia 54, 2006, 1-32.

Točík 1963 - A. Točík: Die Nitra-Gruppe. Archeologické rozhledy 15, 1963, 716-774.

Turek 2010 - J. Turek: Genderové identity v eneolitické společnosti a otázky interpretace společenských kategorií. Živá archeologie 12/2010, 58-63.

Vaněček 2014 - Z. Vaněček: Vyhodnocení otisků na povrchu nádoby nitranské kultury. Nepublikovaný rukopis ze dne 3. 1. 2014

Veliačik 1969 - L. Veliačik: Archeologický výskum v Čiernom Brode (okr. Galanta) roku 1966. Študijné zvesti AÚ SAV 13, 1969, 111-126.

Vladár 1971 - J. Vladár: K problematike medenej industrie tvaru vŕbového listu. Sborník prací Filozofické fakulty Brněnské university E16, 1971, 93-98.

Mgr. Eva Schimerová

Univerzita Hradec Králové

Katedra archeologie

Rokitanského 62

CZ - 50002 Hradec Králové

eva.schimerova@uhk.cz 


\title{
Settlement and Cemetery of Nitra Culture from Hulín 3-U Potůčku
}

\author{
Eva Schimerová
}

SUMMARY

In 2005-2006 a new settlement and cemetery of the Nitra culture was uncovered. Five settlement features contained only few finds. The features were spread in a semi-cicular pattern with a space in between. The cemetery had 101 graves with very little inventory. There were found ceramic vessels, one of them decorated with cord impressions. Copper

Fig. 1. Hulín 3-U Potůčku. 1 - general plan of excavated area from all seasons; 2 - plan of the cemetery; 3 - layout of settlement features dated to Nitra culture; 4 radiocarbon dates obtained from graves (after Peškal Tajer 2015, 7).

Fig. 2. Hulín 3-U Potůčku. 1 - part of mug from feature 16; 2 - jug from grave $65 ; 3$ - mug from grave $74 ; 4$ - mug from grave $57 ; 5$ - vessel from grave 79 (drawings by $\mathrm{M}$. Schindlerová); 6 - lower part of vessel from feature 19 with barley grain impressions (photo by E. Schimerová); 7 - detail of impressions; 8 - wax impression of barley grains (photo by Z. Vaněček).

Fig. 3. Hulín 3-U Potůčku. 1-5, 8 - round wire decorations and willow leaf shape decorations; $6-7-$ willow artifacts including willow leafs. Also chipped stone industry including arrowheads and rare flint dagger. Polished stone industry was also present - wristguards, hammeraxe and miniature hammeraxe. Finally there were bone beads and bone tools. The cemetery is dated to early or classical phase of the Nitra culture, which is confirmed by ${ }^{14} \mathrm{C}$ dates.

leaf shaped knives; 9 - part of dagger; 10 - bracelet (drawings by E. Schimerová).

Fig. 4. Hulín 3-U Potůčku. 1-10 - arrowheads; 11 - miniature hammeraxe; 12-14 - wristguards; 15 - hammeraxe (drawings by J. Brenner).

Fig. 5. Flint daggers. 1, 2 - Hulín 3-U Potůčku, grave 93 (drawing by B. Ludikovská, photo by M. Bém); 3 - Hulín 3-U Potůčku, grave 93, dagger in situ (photo by T. Berkovec); 4 - Hulín 1, feature 186, fragment of a dagger (photo by E. Schimerová).

Table 1. Hulín 3-U Potůčku. Representation of age and sex categories at the cemetery. 